\title{
ПРОБЛЕМНЫЕ РЕГИОНЫ РЕСПУБЛИКИ БЕЛАРУСЬ: СОСТОЯНИЕ И НАПРАВЛЕНИЯ РАЗВИТИЯ
}

\section{Г.В. Петрашевич ${ }^{*}$}

На основе авторских методических подходов к отбору проблемных регионов в Республике Беларусь и экономических расчетов основных показателей их развития выявлены 6 типов регионов, произведена оценка их социально-экономического и экологического развития в 2015-2019 гг., в том числе в сравнении со среднереспубликанским уровнем. Обоснованы предложения и комплекс мер по каждому из регионов, реализация которых позволит достичь сбалансированности в развитии, решении социальных и экологических проблем, выровнять условия и уровень жизни населения регионов.

Ключевые слова: проблемный регион, типы проблемных территорий, социально-экономическое и экологическое развитие регионов.

JEL-классификация: R11, R12, R58.

DOI: $10.46782 / 1818-4510-2021-3-125-137$

Материал поступил 18.08.2021 2.

Стратегическая цель государственной региональной политики Республики Беларусь - создать в регионах равные возможности для достижения высокого уровня и качества жизни населения на основе реализации личностного потенциала и удовлетворения потребностей граждан, рационального размещения производительных сил, эффективного, сберегающего и развивающего использования ресурсов ${ }^{1}$.

Выделение различных типов проблемных регионов в качестве объектов региональной политики Беларуси позволяет сконцентрировать усилия органов государственного управления на решении возникших социально-экономических и экологических проблем, что позволит сократить уровень межрегиональной дифференциации как внутри страны, так и между ее регионами и тем самым создать благоприятные условия жизнедеятельности людей независимо от места их проживания.

Вопросы идентификации проблемных регионов как объектов управления государ-

1 Национальная стратегия устойчивого развития Республики Беларусь до 2035 года. URL: http://www.economy. gov.by/uploads/files/ObsugdaemNPA/NSUR-2035-1.pdf ственной политики социально-экономического развития рассмотрены в работах В.С. Фатеева ${ }^{2}$, В.Н. Шимова ${ }^{3}$, которые дали научные определения и выделили основные типы проблемных регионов.

С учетом мнений других исследователей можно дать следующее определение проблемного региона.

Проблемный регион - административно-территориальная единица базового уровня (район) (далее - ATE), имеющая ряд проблем социально-экономического и экологического развития, препятствующих нормальному функционированию хозяйственного комплекса территории и создающая неблагоприятные условия жизни для проживающего населения, которая не способна самостоятельно их преодолеть, что требует реализации мер государственной поддержки ${ }^{4}$. Ос-

2 Фатеев В.С. 2004. Региональная политика: теория и практика. Минск: ЕГУ. 480 с.

3 Шимов В.Н. (Ред.) 2018. Национальная экономика Беларуси. Минск: БГЭУ. 650 с.

4 Петрашевич Г.В. 2021. Проблемные регионы как объект государственного регулирования социально-экономического развития территорий. Экономический бюллетень НИЭИ Министерства экономики Республики Беларусь. № 2. С. $52-63$.

* Петрашевич Георгий Владимирович (georgii_petrashevich@tut.by), Научно-исследовательский экономический институт Министерства экономики Республики Беларусь (г. Минск, Беларусь). https://orcid.org/0000-0003-2170-881X 
новной целью государственной политики социально-экономического развития проблемных регионов является сокращение социально-экономических различий между проблемными регионами и внутри них, а также содействие сбалансированному и устойчивому развитию всей территории страны.

В Республике Беларусь определен механизм отнесения районов и городов областного подчинения к территориям, отстающим по уровню социально-экономического развития ${ }^{5}$.

Главным отличием предлагаемых нами методических подходов к отбору проблемных регионов является более широкий перечень из 17-ти показателей, позволяющих полнее учитывать не только экономическую, но и социальную и экологическую составляющие устойчивого развития. В то время как в существующей методике отбора отстающих территорий (по 6 показателям) отсутствуют показатели для оценки экологической обстановки и уровня обеспеченности объектами социальной инфраструктуры, а также состояния промышленности, сельского хозяйства и внешнеэкономической деятельности. При этом в Республике Казахстан в методике оценки потенциала сельских населенных пунктов ${ }^{6}$ применяется 15 показателей, в Украине в методике проведения мониторинга и оценки результативности реализации государственной региональной политики ${ }^{7}-64$ показателя.

Предлагаемая концепция выделения проблемных регионов является продолжением тех основ, которые заложены в Плане развития отдельных регионов, отстающих по уровню социально-экономического развития ${ }^{8}$, и позво-

${ }^{5}$ Постановление Совета Министров Республики Беларусь от 2 февраля 2019 г. № 74 «Об утверждении порядка отнесения административно-территориальных единиц к территориям, отстающим по уровню социально-экономического развития». URL: http://www.government.by/ upload/docs/file3e1b0a660c08b501.PDF

${ }^{6}$ Приказ Министра национальной экономики Республики Казахстан от 13 сентября 2019 года № 81 «Об утверждении критериев для определения сельских населенных пунктов». URL: https://adilet.zan.kz/rus/docs/V1900019394\#z10

7 Постановление Кабинета Министров Украины от 21 октября 2015 г. № 856 «Об утверждении Порядка и Методики проведения мониторинга и оценки результативности реализации государственной региональной политики». URL: https://zakon.rada.gov.ua/laws/show/856-2015-\%D0\%BF/print

8 Постановление Совета Министров Республики Беларусь от 9 октября 2019 г. № 689 «Об утверждении плана развития отдельных регионов, отстающих по уровню социально-экономического развития». URL: http://pda. government.by/upload/docs/file6354ea6405132e7d.PDF ляет более углубленно изучить причины, препятствующие устойчивому развитию территорий страны, в том числе вызвавшие их отставание от республиканского уровня.

На основе методических подходов исследователей к типологизации территорий, которые рассмотрены в работах ${ }^{9}$ (Алпеева, Молчанова, Сысоев, 2020; Берченко, Мазан, 2020; Будько, Селюжицкая, 2019; Вохмянин, 2016; Назаров, 2019; Павлова, 2021; Тихий, Иванов, 2018), разработаны авторские методические подходы к отбору проблемных регионов и определены 6 их групп ${ }^{10}$.

Для каждой из 6 групп характерны различные проблемы, что позволило выделить 3 группы проблемных АТЕ, имеющих низкие значения индикаторов по одному из блоков - экономическому, социальному и экологическому, а также дополнительно 3 группы проблемных ATE c низкими значениями индикаторов сразу по двум блокам.

На основе анализа критериев социально-экономического и экологического развития регионов различных типов нами проведены расчеты системы показателей уровня социально-экономического и экологического развития проблемных регионов Республики Беларусь за 2015-2019 гг. и выделены 6 типов проблемных регионов (всего 76 из 118 ATE базового уровня по итогам 2019 г.), которые включают следующие группы:

I. Территории с преимущественно экономическими проблемами (15 ATE);

II. Территории с социальными проблемами (15 ATE);

III. Территории с экологическими проблемами (21 ATE);

IV. Территории с социально-экономическими проблемами (15 ATE);

$\mathrm{V}$. Территории с экономико-экологическими проблемами (7 ATE);

VI. Территории с социально-экологическими проблемами (3 ATE).

${ }^{9}$ Бураков Н.А., Бухвальд Е.М., Кольчугина А.В., Рубинштейн А.Я., Славинская О.А., Слуцкин Л.Н. 2019. Региональный индекс экономического развития и ранжирование субъектов Российской Федерации. Москва: Институт экономики РАН. 72 с.

${ }^{10}$ Петрашевич Г.В. 2021. Методические подходы к отбору проблемных регионов Республики Беларусь. Экономический бюллетень НИЭИ Министерства экономики Республики Беларусь. № 6. С. 48-60. 
По каждой группе проблемных регионов произведена оценка социально-экономического и экологического развития на основе имеющихся официальных статистических данных по показателям, характеризующим текущее состояние промышленности, сельского хозяйства, внешнеэкономической сферы, финансов, инвестиций и жилищного строительства, занятости и оплаты труда, а также выбросов загрязняющих веществ ${ }^{11}$.

В 2019 г. по сравнению с 2015 г. в проблемных АТЕ страны произошло увеличение объемов промышленного производства на душу населения, однако не был достигнут среднереспубликанский уровень. Рост отмечается в 5-ти из 6-ти групп ATE, сокращение произошло только по группе с социально-экологическими проблемами. В 2019 г. по сравнению с 2015 г. темпы роста данного показателя в сопоставимых ценах в целом по группе проблемных ATE превышают темпы роста среднереспубликанского показателя на 4,0 п. П., что является положительной тенденцией. По объему промышленного производства на душу населения лидировали группы территорий с экологическими проблемами $(237,7$ к среднереспубликанскому уровню), допустили отставание территории с социально-экологическими и социально-экономическими проблемами (23,0 и 29,5\% к среднереспубликанскому уровню соответственно).

Наибольший объем промышленного производства на душу населения в 2019 г. имели проблемные ATE Витебской, Гомельской и Минской областей $(132,9,196,5$ и 153,5\% к уровню республики соответственно), в то время как проблемные АТЕ Брестской области 60,5\%, Могилевской - 59,9\%. В 2019 г. по сравнению с 2015 г. в проблемных АТЕ всех областей произошло увеличение объемов промышленного производства на душу населения. Темпы роста данного показателя в сопоставимых ценах в целом в проблемных АТЕ всех областей, кроме Витебской, превышают темпы роста среднереспубликанского показателя.

В проблемных ATE страны в 2019 г. по сравнению с 2015 г. произошло снижение

${ }^{11}$ Петрашевич Г.В. 2021. Методические подходы к отбору проблемных регионов Республики Беларусь. Экономический бюллетень НИЭИ Министерства экономики Республики Беларусь. № 6. С. 48-60. объемов реализации скота и птицы в сельскохозяйственных организациях на душу населения, но уровень проблемных АТЕ превысил средний по республике. По объему реализации скота и птицы в сельскохозяйственных организациях на душу населения лидировали группы территорий с социальными и экологическими проблемами $(225,4$ и $145,1 \%$ к среднереспубликанскому уровню соответственно), допустили отставание территории с экономическими проблемами (56,7\% к среднереспубликанскому уровню).

Наибольший объем реализации скота и птицы в сельскохозяйственных организациях на душу населения в 2019 г. имели проблемные ATE Брестской, Гродненской и Минской областей $(115,7,131,4$ и 131,7\% к среднему уровню республики соответственно), в то время как проблемные АТЕ Могилевской области - 71,1\%. В 2019 г. по сравнению с 2015 г. только в проблемных АТЕ Витебской и Минской областей произошло увеличение объемов реализации скота и птицы на душу населения. Темпы роста данного показателя в сопоставимых ценах в целом по проблемным ATE, расположенным в остальных областях, были ниже темпов роста среднереспубликанского показателя.

В 2019 г. по сравнению с 2015 г. в проблемных ATE страны объемы производства молока в сельскохозяйственных организациях на душу населения снизились, но были выше среднереспубликанских. По этому показателю лидировали группы территорий с социально-экологическими и социальными проблемами (380,2 и 256,3\% к среднереспубликанскому уровню соответственно), допустили отставание территории с экономическими проблемами (88,9\% к среднереспубликанскому уровню).

Наибольший объем производства молока в сельскохозяйственных организациях на душу населения в 2019 г. имели проблемные АТЕ Брестской, Гродненской и Минской областей $(246,3,165,2$ и 154,5\% к уровню республики соответственно), в то время как наименьший объем производства молока был в проблемных АТE Витебской области - 109,0\%. В 2019 г. по сравнению с 2015 г. только в Брестской области произошло увеличение объемов производства молока на душу населения. Темпы роста 
данного показателя в сопоставимых ценах в целом по остальным областям были ниже темпов роста среднереспубликанского показателя.

В проблемных ATE страны в 2019 г. по сравнению с 2015 г. увеличились объемы экспорта товаров на душу населения, но не достигли среднереспубликанского уровня. По этому показателю лидировала группа территорий с экологическими проблемами (161,1\% к среднереспубликанскому уровню), а все остальные группы территорий имели объем экспорта товаров значительно ниже среднереспубликанского. Так, наименьший уровень данного показателя характерен для территорий с социально-экономическими проблемами (9,7\% к среднереспубликанскому уровню).

Наибольший объем экспорта товаров на душу населения в 2019 г. имели проблемные ATE Минской области (235,7\% к уровню республики соответственно), в то время как у проблемных ATE, расположенных в остальных областях, объем экспорта товаров значительно ниже среднереспубликанского: от $37,4 \%$ в Брестской области до 87,4\% в Гомельской области. В 2019 г. по сравнению с 2015 г. произошло увеличение объемов экспорта товаров на душу населения проблемных ATE во всех областях. Темпы роста данного показателя в сопоставимых ценах в целом по всем областям, кроме Витебской области, были выше темпов роста среднереспубликанского показателя и составили от $125,2 \%$ в Брестской области до 273,1\% в Гродненской области.

В проблемных ATE страны в 2019 г. по сравнению с 2015 г. увеличились объемы экспорта услуг на душу населения, но были ниже среднереспубликанских. По объему экспорта услуг на душу населения лидировала группа территорий с экологическими проблемами (37,9\% к среднереспубликанскому уровню), все группы территорий имели объем экспорта услуг значительно ниже среднереспубликанского. Так, наименьший уровень данного показателя характерен для территорий с социально-экономическими и социальными проблемами.

Наибольший объем экспорта услуг на душу населения в 2019 г. имели проблемные ATE Минской области (75,7\% к уровню рес- публики), в то время как у проблемных ATE всех областей объем экспорта услуг значительно ниже среднереспубликанского, наименьший уровень - 4,8\% - в проблемных ATE Могилевской области. В 2019 г. по сравнению с 2015 г. произошло увеличение объемов экспорта услуг на душу населения проблемных ATE во всех областях, кроме Гомельской. Темпы роста данного показателя в сопоставимых ценах в целом в проблемных ATE большинства областей, кроме Витебской и Гомельской, были выше темпов роста среднереспубликанского показателя и составили от 198,0\% в Брестской области до 251,2\% в Минской области.

В 2019 г. по сравнению с 2015 г. в проблемных ATE страны увеличились объемы инвестиций в основной капитал на душу населения, в то время как по республике отмечено снижение. Уровень показателя проблемных АТЕ был ниже среднереспубликанского. По объему инвестиций в основной капитал на душу населения лидировала группа территорий с экологическими проблемами (160,3\% к среднереспубликанскому уровню). Все группы территорий, кроме группы с экологическими проблемами, имели объем инвестиций в основной капитал ниже среднереспубликанского. Так, наименьший уровень данного показателя характерен для территорий с социальными и с экономическими проблемами (58,6 и $60,2 \%$ соответственно).

Наибольший объем инвестиций в основной капитал на душу населения в 2019 г. имели проблемные АТЕ Гомельской и Минской областей (132,6 и 188,3\% к уровню республики соответственно), в то время как у проблемных ATE всех остальных областей объем инвестиций в основной капитал ниже среднереспубликанского: от 57,9\% в Могилевской области до 88,8\% в Гродненской области. В 2019 г. по сравнению с 2015 г. произошло увеличение объемов инвестиций в основной капитал на душу населения проблемных АTE во всех областях, кроме Гомельской и Могилевской. Темпы роста данного показателя в сопоставимых ценах в целом в проблемных АТЕ большинства областей, кроме Гомельской и Могилевской, были выше темпов роста среднереспубликанского показателя и со- 
ставили от 103,2\% в Витебской области до 180,8\% в Минской области.

В проблемных ATE страны в 2019 г. по сравнению с 2015 г. выручка от реализации продукции, товаров, работ, услуг на душу населения выросла, но не достигла среднереспубликанского уровня. По этому показателю лидировала группа территорий с экологическими проблемами (109,8\% к среднереспубликанскому уровню). Все группы территорий, кроме группы с экологическими проблемами, имели выручку от реализации продукции значительно ниже среднереспубликанской. Так, наименьший уровень данного показателя характерен для территорий с социально-экономическими и социально-экологическими проблемами.

Наибольшую выручку от реализации продукции на душу населения имели в 2019 г. проблемные ATE Гомельской и Минской областей (85,3 и 88,9\% к среднему уровню республики соответственно), в то время как у проблемных ATE всех областей выручка от реализации продукции ниже среднереспубликанской, наименьший уровень - 35,0\% - в проблемных ATE Moгилевской области. В 2019 г. по сравнению с 2015 г. произошло увеличение выручки от реализации продукции на душу населения в проблемных ATE всех областей. Темпы роста данного показателя в сопоставимых ценах в целом в проблемных АТЕ большинства областей, кроме Брестской, Витебской и Могилевской $(109,6,106,4$ и 108,9\% соответственно), были выше темпов роста среднереспубликанского показателя и составили от $129,0 \%$ в Гродненской области до $152,5 \%$ в Минской области.

В проблемных ATE страны в 2019 г. по сравнению с 2015 г. номинальная начисленная среднемесячная заработная плата выросла, но не достигла среднереспубликанского уровня. По этому показателю лидировала группа территорий с экологическими и экономико-экологическими проблемами (95,9 и $80,3 \%$ к среднереспубликанскому уровню соответственно). Все группы территорий имели уровень номинальной начисленной среднемесячной заработной платы ниже среднереспубликанского, наименьший уровень характерен для территорий с социально-экономическими и социальными проблемами
(69,5 и 69,8\% к среднереспубликанскому уровню соответственно).

Наибольший уровень номинальной начисленной среднемесячной заработной платы в 2019 г. имели проблемные АТЕ Минской области (106,3\% к среднему уровню республики), в то время как у проблемных АТЕ всех остальных областей уровень номинальной начисленной среднемесячной заработной платы ниже среднереспубликанского: от 75,5\% в Могилевской области до $84,4 \%$ в Гомельской области. В 2019 г. по сравнению с 2015 г. произошел рост данного показателя в проблемных АТЕ всех областей.

Объем розничного товарооборота на душу населения в проблемных ATE страны вырос в 2019 г. по сравнению с 2015 г., но не достиг среднереспубликанского уровня. По этому показателю лидировала группа территорий с экологическими проблемами $(81,2 \%$ к среднереспубликанскому уровню). Все группы территорий имели объем розничного товарооборота ниже среднереспубликанского, наименьший уровень характерен для территорий с социально-экономическими и социальными проблемами (59,6\% к среднереспубликанскому уровню для каждой группы).

Наибольший объем розничного товарооборота на душу населения имели в 2019 г. проблемные ATE Гродненской и Минской областей (86,4 и 84,3\% к среднему уровню республики соответственно), в то время как у проблемных ATE всех областей объем розничного товарооборота ниже среднереспубликанского, наименьший уровень - 69,3\% в проблемных ATE Могилевской области. В 2019 г. по сравнению с 2015 г. произошло увеличение объема розничного товарооборота на душу населения проблемных АTE во всех областях. Темпы роста данного показателя в сопоставимых ценах в целом проблемных ATE в большинстве областей, кроме Витебской, Гомельской и Могилевской $(101,4,103,1$ и 105,6\% соответственно), были выше темпов роста среднереспубликанского показателя. Наибольшие темпы роста характерны для проблемных ATE Брестской и Гродненской областей.

Выбросы загрязняющих веществ на душу населения в проблемных АТЕ страны в 2019 г. по сравнению с 2015 г. снизились, но остались вдвое выше среднереспубликан- 
ского уровня. Сокращение выбросов загрязняющих веществ на душу населения является положительной тенденцией. По этому показателю лидировали группы территорий с экологическими и социально-экологическими проблемами $(351,1$ и 205,1\% к среднереспубликанскому уровню соответственно). Все группы территорий, кроме групп с экономическими $(68,5 \%)$ и социально-экономическими (93,9\%) проблемами, имели выбросы загрязняющих веществ значительно выше среднереспубликанских.

Наибольший объем выбросов загрязняющих веществ на душу населения в 2019 г. отмечен в проблемных АTE Витебской и Гомельской областей $(325,4$ и $227,4 \%$ к среднему уровню республики соответственно), в то время как проблемные ATE всех областей имели выбросы загрязняющих веществ выше среднереспубликанских, наименьший уровень 108,6\% - был отмечен в проблемных АТЕ Минской области. В 2019 г. по сравнению с 2015 г. произошло сокращение объемов выбросов загрязняющих веществ на душу населения в проблемных ATE Гомельской, Гродненской, Минской и Могилевской областей. Темпы роста данного показателя в проблемных ATE большинства областей, кроме Брестской, Витебской и Могилевской $(107,3,104,8$ и 96,3\% соответственно), были ниже темпов роста среднереспубликанского показателя.

Уровень развития проблемных регионов в 2019 г. опережал среднереспубликанский по объему промышленного производства на душу населения (116,6\% к среднереспубликанскому показателю), объему реализации скота и птицы в сельскохозяйственных организациях (108,0\%), объему производства молока в сельскохозяйственных организациях (155,4\%) и объему выбросов загрязняющих веществ $(183,2 \%)$. Следует отметить, что в группу проблемных регионов вошли территории с высоким уровнем выбросов загрязняющих веществ, что связано с большим количеством промышленных предприятий, расположенных на территориях данной группы, а также территории с сельскохозяйственной специализацией, где недостаточными темпами развиваются экономика и социальная инфраструктура.

Отставание проблемных регионов от среднереспубликанского показателя про- изошло по объему экспорта товаров на душу населения $(78,1 \%)$, объему экспорта услуг на душу населения (18,3\%), объему инвестиций в основной капитал $(97,9 \%)$, выручке от реализации продукции $(59,2 \%)$, номинальной начисленной среднемесячной заработной плате $(83,5 \%)$ и объему розничного товарооборота $(75,6 \%)$.

Недостаточное развитие внешней торговли, инвестиционной активности как важнейших составляющих экономического роста проблемных регионов обуславливает отставание по уровню доходов и потребления.

Сравнение показателей выполнено путем расчета темпов роста в сопоставимых ценах с помощью метода цепных индексов. Анализ динамики развития проблемных регионов в сравнении со среднереспубликанскими темпами за 2015 и 2019 гг. показывает рост следующих показателей: объема промышленного производства (116,8 против $112,8 \%$ ) и выбросов загрязняющих веществ (96,9 против 93,2\%), что соответствует превышению среднереспубликанского показателя и объема экспорта товаров (139,4 против 123,9\%), объема инвестиций в основной капитал (101,1 против 98,1\%), выручки от реализации продукции (119,5 против 119,0\%), по которым, несмотря на положительные темпы роста, не был превышен среднереспубликанский уровень.

Динамика социально-экономического и экологического развития проблемных ATE в разрезе групп территорий в сравнении со средними показателями по Республике Беларусь за 2015 и 2019 гг. приведена в табл. 1-3.

Динамика социально-экономического и экологического развития проблемных ATE в разрезе регионов в сравнении со средними показателями по Республике Беларусь за 2015 и 2019 гг. приведена в таблицах 4-6.

Для достижения сбалансированного комплексного развития страны путем устранения негативных факторов, влияющих на развитие проблемных регионов, следует решить ряд задач.

Первая группа - территории с преимущественно экономическими проблемами.

Следует назвать Ушачский район, а также Ошмянский район, который имеет 
Проблемные регионы Республики Беларусь: состояние и направления развития

Таблица 1

Основные производственные объемные показатели проблемных АТЕ в разрезе групп территорий в сравнении со средними показателями по Республике Беларусь

\begin{tabular}{|c|c|c|c|c|c|c|c|c|c|}
\hline \multirow{3}{*}{ Показатель } & \multirow{2}{*}{ Ед. изм. } & \multirow{2}{*}{$\begin{array}{l}\text { Республика } \\
\text { Беларусь }\end{array}$} & \multirow{2}{*}{$\begin{array}{l}\text { Проблемные } \\
\text { АТЕ, всего }\end{array}$} & \multicolumn{6}{|c|}{ в том числе в разрезе групп территорий } \\
\hline & & & & I & II & III & IV & V & VI \\
\hline & & & & & 2015 г. & & & & \\
\hline \multirow{6}{*}{$\begin{array}{l}\text { Объем } \\
\text { промышленного } \\
\text { производства } \\
\text { на душу } \\
\text { населения }\end{array}$} & тыс. руб. & 77936,8 & 87397,5 & 48734,5 & 19102,8 & 179709,9 & 22409,9 & 39215,9 & 35935,1 \\
\hline & $\%^{*}$ & 93,4 & 94,3 & 96,0 & 84,4 & 102,4 & 88,5 & 80,0 & 107,1 \\
\hline & \multicolumn{9}{|c|}{2019 г. } \\
\hline & руб. & 12223,2 & 14246,6 & 7425,8 & 4720,3 & 29054,8 & 3609,0 & 7512,7 & 2806,8 \\
\hline & $\% *$ & 101,0 & 98,9 & 104,6 & 143,9 & 93,7 & 102,3 & 104,6 & 61,5 \\
\hline & \begin{tabular}{|c|}
2019 г. \\
к уровню \\
2015 г.* \\
\end{tabular} & 112,8 & 116,8 & 109,1 & 177,0 & 115,8 & 115,4 & 137,2 & 55,9 \\
\hline \multirow{7}{*}{$\begin{array}{l}\text { Реализация } \\
\text { скота и птицы } \\
\text { в с/х } \\
\text { организациях } \\
\text { на душу } \\
\text { населения }\end{array}$} & \multicolumn{9}{|c|}{2015 г. } \\
\hline & кг & 163,9 & 195,6 & 89,4 & 231,7 & 227,5 & 137,7 & 129,5 & 402,0 \\
\hline & $\%$ & 108,1 & 100,5 & 106,8 & 111,6 & 97,1 & 99,2 & 130,8 & 104,5 \\
\hline & \multicolumn{9}{|c|}{2019 г. } \\
\hline & Кг & 173,2 & 187,1 & 98,3 & 390,5 & 251,3 & 163,1 & 137,3 & 196,9 \\
\hline & $\%$ & 100,3 & 94,4 & 102,5 & 156,0 & 89,9 & 97,1 & 106,5 & 47,6 \\
\hline & $\begin{array}{c}2019 \text { г. } \\
\text { к уровню } \\
2015 \text { г. }\end{array}$ & 105,7 & 95,6 & 109,9 & 168,5 & 110,5 & 118,5 & 106,0 & 49,0 \\
\hline \multirow{7}{*}{$\begin{array}{l}\text { Производство } \\
\text { молока в с/x } \\
\text { организациях } \\
\text { на душу } \\
\text { населения }\end{array}$} & \multicolumn{9}{|c|}{2015 г. } \\
\hline & кг & 699,4 & 1187,3 & 540,4 & 1799,6 & 1263,9 & 1161,0 & 826,5 & 2303,0 \\
\hline & $\%$ & 106,1 & 101,4 & 97,6 & 107,2 & 105,5 & 116,1 & 118,5 & 102,6 \\
\hline & \multicolumn{9}{|c|}{2019 г. } \\
\hline & Кг & 750,6 & 1166,0 & 667,0 & 1923,9 & 1433,4 & 1335,9 & 937,6 & 2853,8 \\
\hline & $\%$ & 101,3 & 101,3 & 107,9 & 104,1 & 107,8 & 104,8 & 104,4 & 120,1 \\
\hline & $\begin{array}{c}2019 \text { г. } \\
\text { к уровню } \\
2015 \text { г. }\end{array}$ & 107,3 & 98,2 & 123,4 & 106,9 & 113,4 & 115,1 & 113,4 & 123,9 \\
\hline
\end{tabular}

* - темпы роста, скорректированные на индекс потребительских цен.

Источник. Авторская разработка.

Таблица 2

Финансово-экономические показатели проблемных АТЕ в разрезе групп территорий в сравнении со средними показателями по Республике Беларусь

\begin{tabular}{|c|c|c|c|c|c|c|c|c|c|}
\hline \multirow{3}{*}{ Показатель } & \multirow{2}{*}{ Ед. изм. } & \multirow{2}{*}{\begin{tabular}{|} 
Республика \\
Беларусь
\end{tabular}} & \multirow{2}{*}{$\begin{array}{c}\text { Проблемные } \\
\text { АТЕ, всего }\end{array}$} & \multicolumn{6}{|c|}{ в том числе в разрезе групп территорий } \\
\hline & & & & I & II & III & IV & $\mathrm{V}$ & VI \\
\hline & \multicolumn{9}{|c|}{2015 г. } \\
\hline \multirow{6}{*}{ Экспорт товаров на душу населения } & долл. США & 2809,4 & 1950,6 & 1204,9 & 180,2 & 4123,4 & 148,9 & 863,3 & 576,0 \\
\hline & $\%$ & 73,8 & 77,0 & 76,0 & 56,4 & 83,2 & 163,6 & 64,4 & 95,4 \\
\hline & \multicolumn{9}{|c|}{2019 г. } \\
\hline & долл. США & 3481,5 & 2718,9 & 1481,7 & 638,6 & 5609,3 & 337,3 & 1568,2 & 453,3 \\
\hline & $\%$ & 97,4 & 102,3 & 102,9 & 156,1 & 98,4 & 137,3 & 100,6 & 76,7 \\
\hline & \begin{tabular}{|c|}
2019 г. \\
к уровню 2015 г.
\end{tabular} & 123,9 & 139,4 & 123,0 & 354,4 & 136,0 & 226,5 & 181,6 & 78,7 \\
\hline \multirow{7}{*}{ Экспорт услуг на душу населения } & \multicolumn{9}{|c|}{2015 г. } \\
\hline & долл. США & 699,0 & 132,6 & 59,2 & 31,0 & 300,1 & 23,5 & 43,1 & 27,9 \\
\hline & $\%$ & 84,1 & 74,2 & 76,9 & 65,9 & 81,9 & 111,7 & 56,0 & 107,7 \\
\hline & \multicolumn{9}{|c|}{2019 г. } \\
\hline & долл. США & 1016,4 & 186,0 & 106,3 & 35,9 & 385,3 & 32,5 & 74,6 & 69,2 \\
\hline & $\%$ & 109,1 & 98,2 & 121,3 & 99,2 & 89,7 & 96,7 & 98,9 & 381,5 \\
\hline & $\begin{array}{c}2019 \text { г. } \\
\text { к уровню } 2015 \text { г. }\end{array}$ & 145,4 & 140,3 & 179,7 & 116,0 & 128,4 & 138,0 & 173,0 & 247,9 \\
\hline
\end{tabular}


Окончание табл. 2

\begin{tabular}{|c|c|c|c|c|c|c|c|c|c|}
\hline \multirow{2}{*}{ Показатель } & \multirow{2}{*}{ Ед. изм. } & \multirow{2}{*}{$\begin{array}{c}\text { Республика } \\
\text { Беларусь }\end{array}$} & \multirow{2}{*}{$\begin{array}{l}\text { Проблемные } \\
\text { АТЕ, всего }\end{array}$} & \multicolumn{6}{|c|}{ в том числе в разрезе групп территорий } \\
\hline & & & & I & II & III & IV & $\mathrm{V}$ & VI \\
\hline \multirow{7}{*}{$\begin{array}{l}\text { Инвестиции в основной } \\
\text { капитал на душу населения }\end{array}$} & \multicolumn{9}{|c|}{2015 г. } \\
\hline & тыс. руб. & 21829,4 & 20583,0 & 13325,7 & 25840,6 & 27989,0 & 11585,6 & 20282,1 & 18136,0 \\
\hline & $\%^{*}$ & 81,2 & 83,1 & 85,9 & 164,5 & 85,2 & 82,2 & 54,0 & 75,5 \\
\hline & \multicolumn{9}{|c|}{2019 г. } \\
\hline & руб. & 3042,5 & 2979,2 & 1833,0 & 1782,1 & 4878,6 & 2336,5 & 2166,9 & 2437,4 \\
\hline & $\% *$ & 106,6 & 113,3 & 110,7 & 67,1 & 140,7 & 152,1 & 97,2 & 40,9 \\
\hline & $\begin{array}{c}2019 \text { г. } \\
\text { к уровню } \\
2015 \text { г.* }\end{array}$ & 98,1 & 101,1 & 96,1 & 48,2 & 121,7 & 140,8 & 74,6 & 93,9 \\
\hline \multirow{7}{*}{$\begin{array}{l}\text { Выручка от реализации } \\
\text { продукции, товаров, работ, } \\
\text { услуг на душу населения }\end{array}$} & \multicolumn{9}{|c|}{2015 г. } \\
\hline & тыс. руб. & 215065,6 & 127131,0 & 91408,8 & 59801,1 & 220238,2 & 51942,7 & 75308,8 & 73486,5 \\
\hline & \%* & 96,4 & 95,7 & 94,1 & 92,7 & 103,9 & \begin{tabular}{|l|}
87,0 \\
\end{tabular} & 85,1 & 98,0 \\
\hline & \multicolumn{9}{|c|}{2019 г. } \\
\hline & руб. & 36747,6 & 21752,5 & 13464,8 & 9884,3 & 40341,0 & 7630,5 & 12895,6 & 8219,8 \\
\hline & $\%^{*}$ & 106,3 & 101,6 & 105,4 & 120,8 & 97,4 & 102,6 & 102,9 & 85,4 \\
\hline & $\begin{array}{c}2019 \text { г. } \\
\text { к уровню } \\
2015 \text { г.* }\end{array}$ & 119,0 & 119,5 & 102,9 & 115,4 & 127,9 & 102,6 & 119,6 & 78,1 \\
\hline
\end{tabular}

* - темпы роста, скорректированные на индекс-дефлятор ВВП.

Источник. Авторская разработка.

Таблица 3

Уровень жизни населения (включая экологические показатели) проблемных АТЕ в разрезе групп территорий в сравнении со средними показателями по Республике Беларусь

\begin{tabular}{|c|c|c|c|c|c|c|c|c|c|}
\hline \multirow{3}{*}{ Показатель } & \multirow{2}{*}{ Ед. изм. } & \multirow{2}{*}{$\begin{array}{r}\text { Республика } \\
\text { Беларусь } \\
\end{array}$} & \multirow{2}{*}{$\begin{array}{c}\text { Проблемные ATE, } \\
\text { всего }\end{array}$} & \multicolumn{6}{|c|}{ в том числе в разрезе групп территорий } \\
\hline & & & & I & II & III & IV & $\mathrm{V}$ & VI \\
\hline & \multicolumn{9}{|c|}{2015 г. } \\
\hline \multirow{6}{*}{$\begin{array}{l}\text { Номинальная } \\
\text { начисленная } \\
\text { среднемесячная } \\
\text { заработная плата }\end{array}$} & тыс. руб. & 6715,0 & 5845,8 & 5644,7 & 4885,1 & 6644,7 & 4930,2 & 5528,3 & 5204,8 \\
\hline & $\% *$ & 97,7 & 96,6 & 96,4 & 94,7 & 97,9 & 96,0 & 95,1 & 98,3 \\
\hline & \multicolumn{9}{|c|}{2019 г. } \\
\hline & руб. & 1092,9 & 912,7 & 854,7 & 763,0 & 1048,0 & 759,9 & 877,3 & 770,3 \\
\hline & $\%^{*}$ & 106,5 & 105,6 & 104,6 & 106,0 & 104,9 & 106,2 & 106,1 & 104,2 \\
\hline & $\begin{array}{c}2019 \text { г. } \\
\text { к уровню } \\
2015 \text { г.* }\end{array}$ & 124,0 & 118,9 & 115,3 & 119,0 & 120,1 & 117,4 & 120,9 & 112,7 \\
\hline \multirow{7}{*}{$\begin{array}{l}\text { Розничный } \\
\text { товарооборот на душу } \\
\text { населения }\end{array}$} & \multicolumn{9}{|c|}{2015 г. } \\
\hline & тыс. руб. & 36591,5 & 27848,9 & 30226,2 & 21330,9 & 30768,4 & 22757,1 & 27468,9 & 21655,1 \\
\hline & $\%^{*}$ & 96,2 & 97,3 & 95,0 & 90,0 & 98,7 & 103,0 & 97,8 & 96,2 \\
\hline & \multicolumn{9}{|c|}{2019 г. } \\
\hline & руб. & 5235,5 & 3955,8 & 4194,0 & 3121,5 & 4250,6 & 3120,1 & 3702,7 & 3428,4 \\
\hline & $\% *$ & 103,9 & 104,3 & 103,2 & 100,8 & 104,1 & 100,9 & 103,9 & 115,5 \\
\hline & $\begin{array}{c}2019 \text { г. } \\
\text { к уровню } \\
2015 \text { г.* }\end{array}$ & 108,7 & 108,2 & 105,7 & 111,5 & 105,2 & 104,4 & 102,7 & 120,6 \\
\hline \multirow{7}{*}{$\begin{array}{l}\text { Выбросы загрязняющих } \\
\text { веществ на душу } \\
\text { населения }\end{array}$} & \multicolumn{9}{|c|}{2015 г. } \\
\hline & кг & 48,3 & 85,2 & 31,4 & 43,3 & 140,4 & 37,4 & 97,6 & 103,0 \\
\hline & $\%$ & 98,9 & 97,9 & 96,0 & 91,2 & 104,7 & 97,2 & 95,7 & 101,5 \\
\hline & \multicolumn{9}{|c|}{2019 г. } \\
\hline & Кг & 45,0 & 82,5 & 30,8 & 61,0 & 158,1 & 42,3 & 60,2 & 92,3 \\
\hline & $\%$ & 94,2 & 94,1 & 90,4 & 97,1 & 100,1 & 98,2 & 80,3 & 82,0 \\
\hline & $\begin{array}{c}2019 \text { г. } \\
\text { к уровню } \\
2015 \text { г. }\end{array}$ & 93,2 & 96,9 & 98,2 & 141,0 & 112,5 & 113,1 & 61,7 & 89,7 \\
\hline
\end{tabular}

* - темпы роста, скорректированные на индекс потребительских цен.

Источник. Авторская разработка. 
Проблемные регионы Республики Беларусь: состояние и направления развития

Таблица 4

Основные производственные объемные показатели проблемных АТЕ в разрезе регионов в сравнении со средними показателями по Республике Беларусь

\begin{tabular}{|c|c|c|c|c|c|c|c|c|c|}
\hline \multirow{3}{*}{ Показатель } & \multirow{2}{*}{ Ед. изм. $\cdot$} & \multirow{2}{*}{\begin{tabular}{|c|} 
Республика \\
Беларусь
\end{tabular}} & \multirow{2}{*}{$\begin{array}{c}\text { Проблемные } \\
\text { АTE, всего }\end{array}$} & \multicolumn{6}{|c|}{ в том числе по областям } \\
\hline & & & & Брестская & Витебская & Гомельская & Гродненская & Минская & Могилевская \\
\hline & \multicolumn{9}{|c|}{2015 г. } \\
\hline \multirow{6}{*}{$\begin{array}{l}\text { Объем промышленного } \\
\text { производства на душу } \\
\text { населения }\end{array}$} & тыс. руб. & 77936,8 & 87397,5 & 43830,7 & 111587,3 & 147979,2 & 52740,2 & 93874,6 & 45328,9 \\
\hline & $\% *$ & 93,4 & 94,3 & 95,7 & 94,9 & 92,3 & 92,6 & 82,8 & 86,9 \\
\hline & \multicolumn{9}{|c|}{2019 г. } \\
\hline & руб. & 12223,2 & 14246,6 & 7390,9 & 16250,6 & 24015,2 & 12404,3 & 18759,9 & 7326,2 \\
\hline & $\% *$ & 101,0 & 98,9 & 103,5 & 90,9 & 96,3 & 105,9 & 112,4 & 105,0 \\
\hline & $\begin{array}{c}2019 \text { г. } \\
\text { к уровню } \\
2015 \text { г. }\end{array}$ & 112,8 & 116,8 & 120,8 & 104,3 & 116,2 & 168,5 & 143,1 & 115,8 \\
\hline \multirow{7}{*}{$\begin{array}{l}\text { Реализация скота } \\
\text { и птицы в с/х } \\
\text { организациях на душу } \\
\text { населения }\end{array}$} & \multicolumn{9}{|c|}{2015 г. } \\
\hline & кг & 163,9 & 195,6 & 209,5 & 152,9 & 193,1 & 327,5 & 214,3 & 134,9 \\
\hline & $\%$ & 108,1 & 100,5 & 108,9 & 98,9 & 107,7 & 97,4 & 84,2 & 104,0 \\
\hline & \multicolumn{9}{|c|}{2019 г. } \\
\hline & кг & 173,2 & 187,1 & 200,4 & 181,2 & 190,1 & 227,6 & 228,1 & 123,2 \\
\hline & $\%$ & 100,3 & 94,4 & 109,7 & 100,1 & 92,5 & 77,3 & 97,5 & 89,3 \\
\hline & \begin{tabular}{|c|}
2019 г. \\
к уровню \\
2015 г.* \\
\end{tabular} & 105,7 & 95,6 & 95,7 & 118,5 & 98,5 & 69,5 & 106,4 & 91,4 \\
\hline \multirow{7}{*}{$\begin{array}{l}\text { Производство молока } \\
\text { в с/х организациях на } \\
\text { душу населения }\end{array}$} & \multicolumn{9}{|c|}{2015 г. } \\
\hline & кГ & 699,4 & 1187,3 & 1508,8 & 879,6 & 1083,6 & 1790,6 & 1173,0 & 988,3 \\
\hline & $\%$ & 106,1 & 101,4 & 107,3 & 101,9 & 112,3 & 105,4 & 83,0 & 102,5 \\
\hline & \multicolumn{9}{|c|}{2019 г. } \\
\hline & $\kappa \Gamma$ & 750,6 & 1166,0 & 1849,0 & 818,4 & 1048,3 & 1239,6 & 1159,3 & 902,8 \\
\hline & $\%$ & 101,3 & 101,3 & 126,5 & 97,8 & 92,9 & 96,7 & 85,5 & 92,2 \\
\hline & $\begin{array}{r}2019 \text { г. } \\
\text { к уровню } \\
2015 \text { г. } \\
\end{array}$ & 107,3 & 98,2 & 122,5 & 93,0 & 96,7 & 69,2 & 98,8 & 91,3 \\
\hline
\end{tabular}

* - темпы роста, скорректированные на индекс цен производителей промышленной продукции.

Источник. Авторская разработка.

Таблица 5

Финансово-экономические показатели проблемных АТЕ в разрезе регионов в сравнении со средними показателями по Республике Беларусь

\begin{tabular}{|c|c|c|c|c|c|c|c|c|c|}
\hline \multirow{3}{*}{ Показатель } & \multirow{2}{*}{ Ед. изм. } & \multirow{2}{*}{$\begin{array}{c}\text { Республика } \\
\text { Беларусь }\end{array}$} & \multirow{2}{*}{$\begin{array}{c}\text { Проблемные } \\
\text { АТЕ, всего }\end{array}$} & \multicolumn{6}{|c|}{ в том числе по областям } \\
\hline & & & & Брестская & Витебская & Гомельская & Гродненская & Минская & Могилевская \\
\hline & \multicolumn{9}{|c|}{2015 г. } \\
\hline \multirow{6}{*}{$\begin{array}{l}\text { Экспорт товаров } \\
\text { на душу населения }\end{array}$} & долл. США & 2809,4 & 1950,6 & 1041,4 & 1480,6 & 1998,5 & 1017,8 & 4111,6 & 994,8 \\
\hline & $\%$ & 73,8 & 77,0 & 78,2 & 54,3 & 72,8 & 81,7 & 70,1 & 71,8 \\
\hline & \multicolumn{9}{|c|}{2019 г. } \\
\hline & долл. США & 3481,5 & 2718,9 & 1303,3 & 1554,5 & 3043,8 & 2779,4 & 8205,2 & 1434,5 \\
\hline & $\%$ & 97,4 & 102,3 & 99,3 & 82,9 & 103,2 & 103,6 & 120,1 & 117,9 \\
\hline & $\begin{array}{c}2019 \text { г. } \\
\text { к уровню } 2015 \text { г. }\end{array}$ & 123,9 & 139,4 & 125,2 & 105,0 & 152,3 & 273,1 & 199,6 & 144,2 \\
\hline \multirow{7}{*}{$\begin{array}{l}\text { Экспорт услуг } \\
\text { на душу населения }\end{array}$} & \multicolumn{9}{|c|}{2015 г. } \\
\hline & долл. США & 699,0 & 132,6 & 48,1 & 96,8 & 165,4 & 71,9 & 306,1 & 23,3 \\
\hline & $\%$ & 84,1 & 74,2 & 80,9 & 77,0 & 84,1 & 78,6 & 49,1 & 72,9 \\
\hline & \multicolumn{9}{|c|}{2019 г. } \\
\hline & долл. США & 1016,4 & 186,0 & 95,3 & 102,4 & 148,7 & 144,4 & 768,9 & 48,6 \\
\hline & $\%$ & 109,1 & 98,2 & 105,2 & 84,4 & 120,5 & 131,0 & 104,8 & 116,0 \\
\hline & $\begin{array}{c}2019 \text { г. } \\
\text { к уровню } 2015 \text { г. }\end{array}$ & 145,4 & 140,3 & 198,0 & 105,8 & 89,9 & 200,9 & 251,2 & 208,8 \\
\hline
\end{tabular}


Окончание табл. 5

\begin{tabular}{|c|c|c|c|c|c|c|c|c|c|}
\hline \multirow{2}{*}{ Показатель } & \multirow{2}{*}{ Ед. изм. } & \multirow{2}{*}{$\begin{array}{c}\text { Рспублика } \\
\text { Беларусь }\end{array}$} & \multirow{2}{*}{$\begin{array}{c}\text { Проблемные } \\
\text { АТЕ, всего }\end{array}$} & \multicolumn{6}{|c|}{ в том числе по областям } \\
\hline & & & & Брестская & Витебская & Гомельская & Гродненская & Минская & Могилевская \\
\hline \multirow{7}{*}{$\begin{array}{l}\text { Инвестиции } \\
\text { в основной капитал } \\
\text { на душу населения }\end{array}$} & \multicolumn{9}{|c|}{2015 г. } \\
\hline & тыс. руб. & 21829,4 & 20583,0 & 13334,3 & 15385,7 & 34491,2 & 18364,1 & 22129,9 & 17499,1 \\
\hline & $\%^{*}$ & \begin{tabular}{|l|l|}
81,2 &
\end{tabular} & 83,1 & 69,6 & 77,0 & 81,1 & 68,3 & 87,9 & 101,6 \\
\hline & \multicolumn{9}{|c|}{2019 г. } \\
\hline & руб̆. & 3042,5 & 2979,2 & 2248,0 & 2273,4 & 4033,7 & 2701,8 & 5727,9 & 1761,9 \\
\hline & $\% *$ & 106,6 & 113,3 & 110,4 & 91,8 & 116,5 & 94,9 & 146,4 & 125,5 \\
\hline & $\begin{array}{c}2019 \text { г. } \\
\text { к уровню } \\
2015 \text { г.* }\end{array}$ & 98,1 & 101,1 & 117,7 & 103,2 & 81,7 & 102,8 & 180,8 & 70,3 \\
\hline \multirow{7}{*}{$\begin{array}{l}\text { Выручка от } \\
\text { реализации продукции, } \\
\text { товаров, работ, услуг } \\
\text { на душу населения }\end{array}$} & \multicolumn{9}{|c|}{2015 г. } \\
\hline & тыс. руб. & 215065,6 & 127131,0 & 84642,2 & 158927,7 & 159382,0 & 100211,2 & 149572,9 & 82559,0 \\
\hline & $\%^{*}$ & 96,4 & 95,7 & 89,7 & 99,9 & 89,1 & 97,2 & \begin{tabular}{|l|}
93,5 \\
\end{tabular} & 88,1 \\
\hline & \multicolumn{9}{|c|}{2019 г. } \\
\hline & руб. & 36747,6 & 21752,5 & 13277,1 & 24207,8 & 31335,7 & 18505,5 & 32666,1 & 12868,6 \\
\hline & $\%^{*}$ & 106,3 & 101,6 & 104,0 & 101,8 & 96,7 & 103,5 & 113,1 & 102,9 \\
\hline & $\begin{array}{c}2019 \text { г. } \\
\text { к уровню } \\
2015 \text { г.* }\end{array}$ & 119,0 & 119,5 & 109,6 & 106,4 & 137,3 & 129,0 & 152,5 & 108,9 \\
\hline
\end{tabular}

* - темпы роста, скорректированные на индекс-дефлятор ВВП.

Источник. Авторская разработка.

Таблица 6

Уровень жизни населения (включая экологические показатели) проблемных АТЕ

в разрезе регионов в сравнении со средними показателями по Республике Беларусь

\begin{tabular}{|c|c|c|c|c|c|c|c|c|c|}
\hline \multirow{3}{*}{ Показатель } & \multirow{2}{*}{ Ед. изм. } & \multirow{2}{*}{\begin{tabular}{|} 
Республлика \\
Беларусь
\end{tabular}} & \multirow{2}{*}{$\begin{array}{l}\text { Проблемные } \\
\text { АTЕ, всего }\end{array}$} & \multicolumn{6}{|c|}{ в том числе по областям } \\
\hline & & & & Брестская & Витебская & Гомельская & Гродненская & Минская & Могилевская \\
\hline & & & & & 2015 г. & & & & \\
\hline \multirow{6}{*}{$\begin{array}{l}\text { Номинальная } \\
\text { начисленная } \\
\text { среднемесячная } \\
\text { заработная плата }\end{array}$} & тыс. руб. & 6715,0 & 5845,8 & 5395,4 & 5701,4 & 5987,8 & 5393,2 & 6598,2 & 5465,7 \\
\hline & $\% *$ & 97,7 & 96,6 & 94,5 & 94,9 & 97,4 & 96,1 & 93,7 & 95,9 \\
\hline & \multicolumn{9}{|c|}{2019 г. } \\
\hline & руб. & 1092,9 & 912,7 & 861,5 & 890,6 & 922,8 & 861,8 & 1161,3 & 824,6 \\
\hline & $\% *$ & 106,5 & 105,6 & 106,1 & 106,3 & 105,6 & 105,5 & 110,3 & 103,8 \\
\hline & $\begin{array}{c}2019 \text { г. } \\
\text { к уровню } \\
2015 \text { г.* }\end{array}$ & 124,0 & 118,9 & 121,6 & 119,0 & 117,4 & 121,7 & 134,1 & 114,9 \\
\hline \multirow{7}{*}{$\begin{array}{l}\text { Розничный } \\
\text { товарооборот на душу } \\
\text { населения }\end{array}$} & \multicolumn{9}{|c|}{2015 г. } \\
\hline & тыс. руб. & 36591,5 & 27848,9 & 23960,4 & 31634,5 & 26896,3 & 28826,5 & 29555,7 & 26164,2 \\
\hline & $\% *$ & 96,2 & 97,3 & 93,8 & 94,9 & 97,5 & 96,6 & 102,6 & 97,1 \\
\hline & \multicolumn{9}{|c|}{2019 г. } \\
\hline & руб. & 5235,5 & 3955,8 & 3689,3 & 4209,8 & 3639,7 & 4523,2 & 4411,7 & 3625,6 \\
\hline & $\% *$ & 103,9 & 104,3 & 104,3 & 103,0 & 103,6 & 104,5 & 110,7 & 103,0 \\
\hline & $\begin{array}{c}2019 \text { г. } \\
\text { к уровню } \\
2015 \text { г.* }\end{array}$ & 108,7 & 108,2 & 117,3 & 101,4 & 103,1 & 119,5 & 113,7 & 105,6 \\
\hline \multirow{7}{*}{$\begin{array}{l}\text { Выбросы загрязняющих } \\
\text { веществ на душу } \\
\text { населения }\end{array}$} & \multicolumn{9}{|c|}{2015 г. } \\
\hline & кГ & 48,3 & 85,2 & 53,2 & 139,7 & 111,1 & 93,0 & 60,1 & 56,7 \\
\hline & $\%$ & 98,9 & 97,9 & 104,2 & 112,5 & 95,6 & 104,5 & 77,6 & 90,5 \\
\hline & \multicolumn{9}{|c|}{2019 г. } \\
\hline & КГ & 45,0 & 82,5 & 57,0 & 146,5 & 102,4 & 62,6 & 48,9 & 54,6 \\
\hline & $\%$ & 94,2 & 94,1 & 108,7 & 103,4 & 84,9 & 79,6 & 81,8 & 95,3 \\
\hline & $\begin{array}{c}2019 \text { г. } \\
\text { к уровню } \\
2015 \text { г. }\end{array}$ & 93,2 & 96,9 & 107,3 & 104,8 & 92,1 & 67,3 & 81,3 & 96,3 \\
\hline
\end{tabular}

* - темпы роста, скорректированные на индекс потребительских цен.

Источник. Авторская разработка. 
агропромышленную специализацию. Оба характеризуются значительным отставанием от среднереспубликанского уровня по показателям развития промышленности, финансов и внешней торговли.

На ближайшую перспективу необходимо осуществление преобразований по формированию новой структуры хозяйства, наиболее полно отвечающей местным условиям и потребностям населения. Преимущественная специализация - многофункциональная и промышленно-аграрная. Специфика данной группы территорий требует реализации новых инвестпроектов по модернизации действующих производств базовых отраслей экономики, создания новых производств и развития видов деятельности, ориентированных на эффективное использование местных экономических, природных и прочих условий.

В дальнейшем потребуется структурная перестройка региональной экономики, в том числе создание и расширение региональных кластеров и холдингов, включение в их состав новых предприятий параллельно с развитием инфраструктурных систем таких территорий (инженерной и дорожно-транспортной, связи, телекоммуникации).

Особое внимание следует уделить строительству объектов социальной сферы и увеличению объемов жилищного строительства.

Вторая группа - территории с социальными проблемами.

Шарковщинский и Сенненский районы отстают от среднереспубликанского уровня по количеству детей и учащихся в образовательных учреждениях, обеспеченности медицинским персоналам и коечным фондом, а также по уровню доходов и потребления.

Преимущественная специализация этих территорий - аграрная и аграрная с туристско-рекреационной и природоохранной деятельностью. Специфика данной группы территорий требует на ближайшую перспективу предоставления населению гарантированного минимума социально значимых услуг независимо от места проживания (обеспечение выполнения социальных стандартов).

В дальнейшем следует преимущественно развивать сферу обслуживания населения за пределами городов, а именно расширять социальные услуги в сельской мес- тности и малых городах (розничная торговля, здравоохранение и образование).

Необходимо обеспечить снижение кредитной нагрузки на предприятия данной группы территорий.

Третья группа - территории с экологическими проблемами.

Полоцкий и Мозырский районы в данной группе относятся к центрам экономического роста и имеют на своей территории нефтеперерабатывающие заводы, которые являются основными источниками образования вредных выбросов и отходов.

Преимущественная специализация в группе - многофункциональная, агропромышленная и промышленно-аграрная. Специфика этих территорий требует на ближайшую перспективу осуществления содействия естественному развитию экосистем, сохранения и восстановления уникальных природных комплексов, обеспечения рационального использования местных природных ресурсов.

В дальнейшем необходимо размещать новые производительные силы в соответствии с естественными природными и экологическими условиями проблемной территории, внедрять устройства очистки и утилизации отходов, технологические процессы замкнутого цикла на предприятиях данной группы, использовать вторичные ресурсы, перераспределять транспортные потоки на территории городов, создавать филиалы промышленных предприятий в проблемных регионах за пределами крупных городов, строить энергоэффективное жилье (с использованием электрической энергии для водо- и теплоснабжения, приготовления пищи) и стимулировать развитие электротранспорта.

Четвертая группа - территории с социально-экономическими проблемами.

Столинский и Лельчицкий районы подверглись радиоактивному загрязнению в результате катастрофы на Чернобыльской АЭС и отстают от среднереспубликанского уровня как по развитию промышленности, финансов, так и по показателям обеспеченности объектами здравоохранения и образования, а также по уровню доходов и потребления.

Преимущественная специализация группы - аграрная и агропромышленная. 
Специфика этих территорий требует на ближайшую перспективу сохранения рабочих мест (за счет модернизации промышленности), а также развития социальной инфраструктуры и сферы услуг.

В дальнейшем следует осуществлять реструктуризацию промышленных предприятий в проблемных регионах, сильно зависящих от внешнего спроса на мировых рынках, и стимулировать развитие экспортных и импортозамещающих производств в районах, имеющих для этого наиболее благоприятные условия, что позволит недопустить сокращение численности занятого населения. Необходима также реализация комплекса мер по реабилитации загрязненных территорий, максимальному снижению вредного воздействия катастрофы на ЧАЭС на природную среду и население.

Пятая группа - территории с экономико-экологическими проблемами.

Здесь отметим Ганцевичский и Поставский районы, где преимущественно развиваются сельскохозяйственные предприятия, которые выступают главными загрязнителями для данных территорий и не способны обеспечить высокий уровень экономического развития.

Преимущественная специализация группы - промышленно-аграрная. Специфика этих территорий требует на ближайшую перспективу мероприятий по преодолению кризиса производства в районах с худшими природными условиями (неблагоприятных для производства сельхозпродукции, с низким производственным потенциалом).

В дальнейшем важно расширять сферу приложения труда в соответствии с региональными условиями (обслуживание транспортных коридоров, туризм, рекреационная деятельность и др.), развивать малое и среднее предпринимательство, особенно в небольших городах и сельской местности, а также осуществлять техническое и технологическое перевооружение предприятий с целью энерго- и ресурсосбережения и сокращения образования отходов производства.

Необходимо увеличение объемов строительства индивидуального жилья и объектов социальной инфраструктуры, обеспечение транспортной доступности населения.

Шестая группа - территории с социально-экологическими проблемами.
Малоритский и Лиозненский районы характеризуются преимущественным развитием сельского хозяйства, что является причиной экологических проблем. В обоих районах уровень жизни ниже среднего по республике.

Преимущественная специализация группы - аграрная и аграрная с туристско-рекреационной и природоохранной деятельностью. Специфика этих территорий требует на ближайшую перспективу реструктуризации и перепрофилирования предприятий, что позволит обеспечить экологическую безопасность проблемных регионов, а также занятость населения малых городов и поселков городского типа за счет преимущественного размещения в них новых малых и средних организаций, развития агротуризма и ремесленной деятельности.

В дальнейшем необходимо использование особенностей географического положения приграничных территорий: их переспециализация, организация новых приграничных служб и хозяйственных структур, а также развитие логистики этих территорий с целью создания новых рабочих мест, совершенствования социальной инфраструктуры и сферы услуг.

Таким образом, рассмотренная типологизация проблемных территорий, выделенная на основе авторских методических подходов к их отбору, а также предложения по формированию государственной политики социально-экономического и экологического развития в разрезе групп проблемных регионов могут быть использованы при разработке Государственной программы и инвестиционной стратегии развития проблемных территорий Республики Беларусь до 2025 г. с целью достижения сбалансированного комплексного развития страны путем сокращения уровня межрегиональных различий.

\section{СПИСОК ЛИТЕРАТУРЫ (REFERENCES)}

Алпеева Е.А., Молчанова Н.П., Сысоев А.В. 2020. Развитие методики оценки социально-ориентированной инфраструктуры региона. Экономика в промышленности. Т. 13. № 1. С. 78-86. [Alpeeva E.A., Molchanova N.P., Sysoev A.V. 2020. Improving 
the methodology for assessing socio-oriented regional infrastructure. Ekonomika v promyshlennosti. Vol. 13. No 1. PP. 78-86. (In Russ.)]

Берченко Н.Г., Мазан А.С. 2020. Центры и точки роста экономики регионов Республики Беларусь. Экономический бюллетень Научно-исследовательского экономического института Министерства экономики Республики Беларусъ. № 12. С. 517. [Berchenko N.G., Mazan A.S. 2020. Centers and points of regional economic growth of the Republic of Belarus. Ekonomicheskiy byulleten' Nauchnoissledovatel'skogo ekonomicheskogo instituta Ministerstva ekonomiki Respubliki Belarus'. No 12. PP. 5-17. (In Russ.)]

Будько О.Н., Селюжицкая Т.В. 2019. Дифференциация регионов Беларуси по уровню эколого-экономического состояния. Вестник Полоцкого государственного университета. Серия D. Экономические и юридические науки. № 14. С. 10-14. [Budko O.N., Seliuzhytskaya T. 2019. Differentiation of regions of Belarus according to the level of ecological and economic condition. Vestnik Polotskogo gosudarstvennogo universiteta. Seriya D. Ekonomicheskie $i$ yuridicheskie nauki. No 14. PP. 10-14. (In Russ.)]

Вохмянин И.А. 2016. Разработка методического инструментария оценки развития конкурентной среды в отраслях экономики регионов. Белорусский экономический журнал. № 4. С. 75-83.
[Vokhmyanin I.A. 2016. Developing methodological instrumentarium of assessing competitive environment development in regions' economy sectors. Belorusskiy ekonomicheskiy zhurnal. No 4. PP. 75-83. (In Russ.)]

Назаров Ш.X. 2019. Оценка асимметрии в развитии регионов Узбекистана. Экономический бюллетень Научно-исследовательского экономического института Министерства экономики Республики Беларусь. № 11. C. 43-50. [Nazarov Sh. 2019. Assessment of asymmetry in regional development in Uzbekistan. Ekonomicheskiy byulleten' Nauchno-issledovatel'skogo ekonomicheskogo instituta Ministerstva ekonomiki Respubliki Belarus'. No 11. PP. 43-50. (In Russ.)]

Павлова И.Г. 2021. Оценка уровня инновационного развития региона. Вестник Белгородского университета кооперащии, әкономики и права. № 3. C. 147-155. [Pavlova I.G. 2021. Region’s innovative development level assessment. Vestnik Belgorodskogo universiteta kooperatsii, ekonomiki $i$ prava. No 3. PP. 147-155. (In Russ.)]

Тихий В.И., Иванов С.С. 2018. Обеспечение устойчивого социально-экономического развития сельских территорий региона. Региональная экономика: теория и практика. Т. 16. № 8. C. 1467-1480. [Tikhii V.I., Ivanov S.S. 2018. Ensuring sustainable socio-economic development of rural areas of the region. Regional'naya ekonomika: teoriya i praktika. Vol. 16. No 8. PP. 1467-1480. (In Russ.)]

\section{PROBLEMATIC REGIONS OF THE REPUBLIC OF BELARUS: CONDITIONS AND DEVELOPMENT DIRECTIONS}

\section{Heorhi Petrashevich ${ }^{1}$}

Author affiliation: ${ }^{1}$ Economic Research Institute of the Ministry of Economy of the Republic of Belarus (Minsk, Belarus).

Corresponding author: Heorhi Petrashevich (sfkugan@mail.ru).

ABSTRACT. Based on the author's methodological approaches to the selection of troubled regions in the Republic of Belarus and economic calculations of the main indicators of their development, 6 types of regions were identified. Their socio-economic and environmental development in 2015-2019 is assessed, including in comparison with the average republican level. Recommendations and a set of measures for each of the regions are substantiated, the implementation of which is aimed to achieve balanced development, to solve social and environmental problems, level off the conditions and living standards of the population in the regions.

KEYWORDS: problem region, types of problem territories, socio-economic and environmental regional development.

JEL-code: R11, R12, R58.

DOI: $10.46782 / 1818-4510-2021-3-125-137$

Received 18.08 .2021 